\title{
Developing the Directional Abilities through Individualization of the Educational Process
}

\section{Magdalena Christ (MA)}

\author{
Faculty of Pedagogy and Psychology \\ University of Silesia in Katowice (Poland)
}

\author{
Doi:10.5901/jesr.2013.v3n7p413
}

\begin{abstract}
Each person is a unique individual - having different capacities and needs. We have to remember about it especially if we work with children in early education. The aim of this paper is to present the opportunity to develop the directional abilities of children through individualization of educational process. It will show examples of programs and projects that can serve as a model to follow. Its task is also to popularize model of education which is based on the theory of multiple intelligences by $\mathrm{H}$. Gardner. The author of this theory has identified eight intelligences: linguistic intelligence, logical-mathematical intelligence, spatial intelligence, musical intelligence, bodily-kinesthetic intelligence, naturalist intelligence, interpersonal intelligence and intrapersonal intelligence. Most people can develop each intelligence to an adequate level of competency and this paper contains examples of how we can do that. Gardner's work on multiple intelligences has become an important topic of discussion in many corners of educational profession. The theory of multiple intelligences was an inspiration to the research project "Individualization and effectiveness of the education process and the directional abilities of students in an integrated early childhood education "(project tutor prof. S. Juszczyk.) The text contains re flections after the project.
\end{abstract}

Keywords: individualization, individual differences, educational process, directional abilities, theory of multiple intelligences by $\mathrm{H}$. Gardner

\section{Individual differences}

Plato argued that no two people are largely similar to each other. Each person is different with individual characteristics and behavior (Lewowicki, 1977, p. 12). Differences between people are common, meaning that there is not such a physical feature, way if behaving or psychological feature in terms of which people would differ from each other. J. Strelau believes that individual differences is the phenomenon that individuals belonging to the same population differ from one another in terms of physical and psychological characteristics (2006, pp. 23-24). According to B. Hornowski occurring individual differences among people depend on four factors: the influence of heredity, environment, education and teaching system and the activity of the body itself $(1985$, p. 29). This highlights and fully realizes the responsibility which rests on teachers who direct the activities of students, implemented in the learning process. The optimal educational approach should take into account the individual differences that occur between students.

According to E. Piotrowski, to effectively support students to develop their own individuality and provide them with harmonious development, individualization of the educational process is necessary. It should take into account individual student's capabilities, which include: the level of intelligence, creative possibilities, the dominant cognitive style influencing cognitive functioning (2008, p. 425). Equally important to the effective implementation of learning is considering individual differences in the directional capabilities or interests of students.

\section{Individualization of the educational process}

According to J. Bałachowicz, in the modern pedagogical considerations, we find an almost complete acceptance of individualization in education. Individualization is however understood differently once in the category of ideas, sometimes in terms of instrumental activities. Individualization includes ideas and educational objectives related to the development of an individual, but sometimes it only refers to child's individual characteristics and learning opportunities, or it refers to the teaching content and how to make it accessible. The issue of individualization refers to the accuracy of organizing the learning process, and at other times it refers to the correct learning $(2011$, p. 9). E. Skrzetuska also notes that individualization in the process of teaching and learning can be considered from different points of view, both from the theoretical and practical considerations of research on this issue, the opinion of people who carry it out in practice. The modern understanding of the term individualization in teaching-learning arose in the discussion on the effectiveness 
of the education system and therefore mainly refers to organizing work on lessons and methods of student assessment (2011, p. 42). One of the dictionary definition defines this term as the adaptation of teaching to the possibilities, interests and needs of individual students, in which is taken into account: students abilities, the time they need to master specific subjects or topics and pace of learning in children and adolescents (Kupisiewicz, 2009, p. 65). S. Palka explains the term individualized education as the adaptation of content, methods, forms, educational source, requirements, pace of work, monitoring and evaluation for the individual characteristics (eg. the level of intelligence and aptitude), physical abilities of students (eg. microdeficiencies in development). It is to be implemented in order to give a chance of success to each student (2003, p. 120). However W. Okon briefly summarizes that the purpose of individualization in education is to provide maximum opportunities for students of different abilities (2007, pp. 136-137).

As noted by E. Skrzetuska, individualization is the idea of a flexible designing of learning, teaching and education, going deeply though the entire process, including its various ranges, taking into account all the participants (teachers and students), place of education implementation and its surroundings. Diagnosing and promoting individual skills, recognition of cognitive capabilities, existing knowledge and experience, considering ways of learning and developing them, stimulating and directing interests and including self-discovery and tend to stimulate the multiple development of the students in the educational process (2011, p. 57). The great diversity of students shows the need for proper planning of the educational process, taking into account different levels of students' abilities.

\section{General and directional abilities of students}

J. Freeman and co-authors report on global solutions for the education of talented, show that in the world today there are about 100 definitions of the concept of student ability and capability (Dyrda, 2012, p. 60). Such a wealth of definitions poses many difficulties.

T. Lewowicki has written about the division of abilities into general and special. He noted that about general and special abilities Ch. E. Spearman has spoken as one of the first. He uses the name central factor or general factor, as well as special factor. Separation of special abilities, related to specific areas or forms of activity indicates that there is apart from the general ability - the ability to do something, the ability to perform certain activities. And therefore we meet classifications of special abilities modeled on a accepted divisions of human actions. In case of a child it is said, for example, about the language, mathematical, musical, artistic and technical ability, etc. Special abilities are associated with specific business, which is why they are called directional abilities (1977, pp. 95-97). According to W. Limont education of gifted children should be based on the use of all their strengths and weaknesses, the information which is obtained through the analysis of each individual case (2012, p. 101). Further information concerning levels of ability in various areas should provide a multifaceted diagnosis of students.

\section{Theory of multiple intelligences by H. Gardner in the context of diagnosis and support of the development of the directional students' abilities}

In terms of psychometric intelligence is defined as the ability to solve tasks included in the intelligence tests. Noticeable correlation of results among different age groups and different tests confirms that general intelligence does not change much with age and is slightly dependent on education and experience. Gardner's theory of multiple intelligences disputes the traditional approach. Intelligence is here resulting from human biology and psychology, some sort of processing capacity information. The theory of multiple intelligences shows any ability to solve problems in the light of its biological origins, but it deals only with those skills that are universal and characteristic of the human race (Gardner, 2009, pp. 1718). H. Gardner singled out a set of eight intelligences, which include: linguistic, logical-mathematical, visual-spatial, musical, kinesthetic, natural, interpersonal and intrapersonal. The author of the theory has repeatedly stressed that he used the term intelligence in plural deliberately to emphasize that intelligence is more than linguistic or mathematicallogical intelligence but it is possible to be intelligent in many ways. H. Gardner notes that putting logic and language on a pedestal reflects the values of western culture. In a more impartial approach all intelligence is treated as equally valuable. According to $\mathrm{H}$. Gardner naming some of these talents and other intelligences showed some prejudice. According to the theory of multiple intelligences, you may call them all talents, because the name does not matter, if only to refer to all of these abilities (2002, pp. 63-64).

According to $\mathrm{H}$. Gardner, any form of assessment of children should meet three criteria:

- It should be fair to the intelligence - presented in such a way as to be able to observe the potential of the intelligence directly, rather than through the prism of logic and mathematics; 
- It should be appropriate to the level of development of the child - use technology appropriate to its level of development;

- This should be combined with the recommendations - each result and the description should be accompanied by a list of actions or steps that are recommended for a child with a particular profile intelligence (2002, p. 110).

- Identifying characteristics of children's ability is to:

- Obtain information about the strengths and weaknesses of the intellectual processes on the basis of the job, and observation of respondents;

- Development of appropriate exercises that can improve mental functioning of specific students;

- Education management in order to improve intellectual capacity and personal characteristics of the respondents (Eby, Smutny, following: Czelakowska, 2007, p. 167).

$\mathrm{H}$. Gardner at the end of one of his books wondered how it will look to use of the theory of multiple intelligences in 2013. He thought that probably it will change in the years taken in the spirit of educational activities. Rightly he predicted that many attempts will be made to create educational programs that will be taken seriously in multiple intelligences. He believed that one of the areas where progress needs to be made is to develop curricula that will prove to be suitable for people with different profiles collar. He also pointed out that the idea of multiple intelligences should become part of teachers training programs. H. Gardner also emphasized the great need for a thorough investigation of how intelligence is used in various places of work and how it will be used in the future. Tracing the development of a hypothetical picture of the work on the theory of multiple intelligences in 2013 he mentions a numerous possibilities of scientific, educational, institutional and its aftermath possibilities (Gardner, 2002).

In the context of allegations spun by $\mathrm{H}$. Gardner it is worth to mention a realized in a number of Polish school project called "First students experience the way to knowledge". The time frame of the project covered the period from October 2008 till December 2011. It was a project funded by the European Social Fund and the state budget and implemented by the Educational Group S.A. from Kielce. Theoretical base of the project was the theory of multiple intelligences by $\mathrm{H}$. Gardner. His aim was to implement a model of early childhood education that will create a strong foundation for a career as a school and child's life. The project was aimed at about 130000 students from first grade of 2700 schools. At each of the schools involved in the project created the so-called. Interests centers. Children were able to realize the educational activities planned by their teacher responding to their possibilities, abilities and students' interests. This way allowed to carry out a demand of individual training and also opened up space for demonstration of purposes and children's talents (www.pierwszaki.com). The aim of the project was to work with children conducted during leisure activities. A trained teacher diagnosed the students, and learned their profile intelligence. With his knowledge and based on its copyright ideas chose the best scientific methods tailored to the needs and potential of children. The summary of the work on extra-curricular activities were demonstrations of skills of project participants. Of great importance was the collaboration of teachers with parents. Thanks to the collaborabotion parents learned how to support their children in learning at home Educational Group S.A., 2011). Such projects provide great opportunities for a great support of the development of students. All effort should be put to ensure that activities in this area going to be continued in subsequent years.

The theory of multiple intelligences of $\mathrm{H}$. Gardner finds its practical application within the activities of universities for children. The first such initiative was developed at the University of Tübingen in 2002 and University in Vienna in 2003.

In 2009 its activity started Silesian University of Children. This initiative was born out of the belief that all children want to learn and take the joy of learning in different ways and that learning does not have to end when you exit the class. The aim of the Silesian University of Children:

- The development and enhancement of existing interests, knowledge and skills, cognitive arousing curiosity and inspiring to discover new areas of interest, development of the intellect, enthusiasm for learning and personality of its students;

- Showing the benefits of a university education, help children exploration, discovery and starting their own path to success;

- The presentation of diversified educational, open to all abilities and allowing each child discover his talent;

- Ensure that students are exposed to modern science and great research laboratories in Poland and in Europe;

- To develop students' language skills and provide a link to children university students in other countries;

- The development of self-knowledge, interests, sports, mobility and manual skills of students;

- Cooperation of the University of Silesia and its research institutions with the community of the region, 
providing intellectual potential, knowledge and experience of the academic staff of the Silesian University of children.

Students in the age from 5 to 15 years (divided into four age groups) are given where they collect grades.. Lectures include topics such as: Your personal laptop - how to operate a computer in your head; Secrets of view; Fairytale world of puppet theater; Physics of a balloon, The world beneath our feet, which is what whistles in the grass; Colorful world of percussion instruments; Bulb Edison - if everyone can be a genius?, and many others. Children participated in activities in a wide range of excursions, such as the Silesian Zoological Garden. Lectures are also organized for parents, such as Mind map - creative record in memory. In 2011 Students also created the Children's Choir of the Silesian University Children whose repertoire is diverse and includes Polish and foreign children's songs, Polish folk songs, carols (www.dzieci.us.edu.pl). The activities of the Silesian University for Children is very popular, as evidenced by students full of small classrooms.

\section{Our results}

As noted by I. Czaja-Chudyba analysis capability allows the teacher for the student's individualized work, helps in making contact, overcoming the stress of the first day of school. It is a major factor in deciding whether the school will be a place where the student survives intellectual or artistic adventure $(2009$, p. 13). In practice, pedagogical and psychological diagnostic capability are most commonly used:

- tests to assess intelligence, skills and educational attainment or tests of creative thinking;

- competitions;

- observation methods: questionnaires and letters behavioral characteristics of gifted children;

- $\quad$ analysis of the products of children (eg. their drawings, essays, etc.).

Observations should begin in the earliest period of life. They can be run by parents, teachers, and experts. In assessing the ability of children to be further analyzed their interests, learning styles, portfolios recording the development and achievements of the students and the nature of self-evaluation tools (Czaja-Chudyba, 2009, pp. 39-42).

The copyright diagnostic research was conducted in the first two years of primary school. They have been implemented as part of the doctoral thesis entitled "Individualization and effectiveness of the educational process and the directional students abilities of integrated early childhood education" (the promotor is prof. S.Juszczyk). A total of 47 students, their parents and teachers took part in it. One the purpose of this study was to answer the question:

Whether and what relationship exists between the three diagnoses directional abilities of the first grade in the study, created on the basis of information obtained from three sources: parents, teachers, and the observer - the researcher?

Diagnosis of students included:

- Fill in questionnaires for the first grade parents participating in the study;

- $\quad$ Filling in the questionnaires relating to individual teachers of the first grade students participating in the study;

- Conducting observations enabling the researcher to determine the directional abilities of students observations made during diagnostic activities carried out by the first grade teachers participating in the study;

- Research of interests and abilities of students using the directional abilities of students using the authorized tool "Historyjki".

Statistical analysis takes into account three diagnoses - from the perspective of parents, teachers (based on data obtained from questionnaires) and the observer (based on data obtained from observations), since the results were expressed in a spot.

Analysis of variance indicated a lack of equality of means scoring by the researcher, parent and teacher. Average scores directional abilities of students from three different perspectives are included. This shows that the full and valuable diagnosis must take into account a different research perspectives, based on different methods and forms of data collection.

In order to obtain information directly from students about their interests and abilities we have used a tool called "Historyjki" It aims to fully involve students in the process of diagnosis of their interests and the directional abilities. It acquaints the students with the concepts present in the stories. It teaches cooperation within a group and joint decision-making. It improves your concentration because of listening to the text, as well as perception, logical thinking and creativity. Students are asked to listen to the stories of children representing eight types of abilities and adjusts to them appropriate illustration. On the basis of the students' answers, perform additional commands and create an artwork, which helps us to identify their interests and abilities. With children performed tasks focus attention on the characters of 
individual stories. The main goal is to create a tool for children's reference point to themselves, help them to present their interests and abilities. For children it is difficult to directly assess and determine whether an area is their strength capacity or the weaker party. This is often dependent on their sense of self-esteem and their abilities, feedback received by persons significant to the child, such as parents, teachers. The tool allows you to get information about a child through the choices he made, indications, which tends diagnostic classes.

Students participating in the study often communicated a greater capacity. It should be a signal for teachers and parents to provide the child with the conditions in to fully developed interests and athletic ability. A good opportunity to meet the children's needs are activities organized outside the school building - during physical education classes, breaks, walks or hikes. Following the example of the Nordic countries should provide students with more opportunities to learn the fresh air in an all made in the author's research project, diagnoses, regardless of their perspective (parent, teacher or observer - the researcher), was repeated a large number of people having a greater ability to visual- space, which in many cases was associated with artistic abilities. Visual-spatial abilities of children is an area sometimes little appreciated by parents and teachers treated less seriously than the language skills or mathematical logic. This creates a need for continuous push for actual homing in implementing the child's learning abilities, without classifying the important or less important.

Information obtained from a parent, teacher, student and researcher evaluation findings often vary significantly between. It can be affected by many factors. Parent-teacher relationship can not be limited to mutual seriously, respect and recognize the participation in education and socialization of the child, it must first of all mean working (KarwowskaStruczyk, 2007, p. 42). It is the parents of the child that are a valuable source of information on the strengths and weaknesses of a child. Parents have the greatest contact with the child in its natural conditions, however, often do not have a reference point - the comparison operators in the form of other children - so it may be a problem with an objective assessment of your child's ability level. Sometimes, unconsciously or consciously to determine the child's ability as higher than actual. The teacher assesses with a reference in the form of other students, but his observation error may occur as a generalization of the results. If your child has a higher level of capacity in one area, it can also be assessed above in other capacities. Copyright in the present study, a teacher's diagnostic questionnaires completed restoring its previous observations and knowledge of the students, so they can escape the memory of some important facts. It is therefore essential diagnostic tools that help systematic information on individual students, orient the observations. It may also be running portfolios of student work that can illustrate their development, the progress achieved. It should also work with specialists who can help diagnosing students. Remarks investigator should be the most objective and accurate because they were based on deliberately structured diagnostic situations, structured by means of appropriately selected diagnostic tools. The observer did not know the children, which could both facilitate and impede the diagnostic task. Researcher drew conclusions based on observation of specific, deliberately organized situation, yet they accounted for only some selective parts of reality, in which student behavior can be changed with Due to various factors, such as half-hour classes perform more sophisticated, bad weather, bad mood or mood students. Information obtained directly from the students an invaluable complementary to diagnose the level of their ability and direction possible inclusion in a more complete way the students themselves in for the diagnostic process.

\section{Conclusion}

Among the important tasks of the teacher are to develop the ability of all students, regardless of their level, keeping the diagnosis of students with special talents, identify their special needs and conducting activities to meet these needs and providing students the fullest possible development (Jabłonowska, Lukasiewicz-Wieleba, 2010, p. 278). H. Gardner emphasizes wit, that it is vital to identify and cultivation of various kinds of intelligence, and their various combinations. We differ so much among themselves in large measure due to the fact that we all have different combinations of the various intelligence. Should try to use the full range of human capacities so that everyone can get involved in working for the common good $(2009$, p. 41). Therefore, it is necessary to undertake research trials, so you can constantly improve ways of diagnosing profiles of multiple intelligences. Dissemination of diagnostic tools and take care of teachers preparation for their proper use. It is also appropriate to organize the school environment and extracurricular and support the learning process of principle of treating each student as a unique individual. might be favored by un university activities for children, as well as the implementation of educational programs in schools, with an emphasis on individual upgrading the educational process. 


\section{References}

Bałachowicz, J. (2011). Edukacja początkowa wobec potrzeb indywidualnego rozwoju dziecka. In E. Skrzetuska (Eds.), Problemy edukacji wczesnoszkolnej. Indywidualizacja - uzdolnienia - refleksja nauczyciela. Lublin: Wydawnictwo Uniwersytetu Marii CurieSkłodowskiej, pp. 9-22.

Czaja-Chudyba, I. (2009). Jak rozwijać zdolności dziecka?. Warszawa: WSiP.

Czelakowska, D. (2007). Inteligencja i zdolności twórcze dzieci w początkowym okresie edukacji. Kraków: Impuls.

Dyrda, B. (2012). Edukacyjne wspieranie rozwoju uczniów zdolnych. Studium społeczno-pedagogiczne. Warszawa: Wydawnictwo Akademickie ŻAK.

Gardner, H. (2002). Inteligencje wielorakie. Teoria w praktyce. Poznań: Media Rodzina.

Gardner, H. (2009). Inteligencje wielorakie. Nowe horyzonty w teorii i praktyce. Warszawa: Laurum.

Grupa Edukacyjna S.A. (2011). Pierwsze uczniowskie doświadczenia drogą do wiedzy. Kielce.

Hornowski, B. (1985). Psychologia różnic indywidualnych. Warszawa: WSiP.

Jabłonowska, M., Łukasiewicz-Wieleba, J. (2010). Model pracy z uczniem szczególnie uzdolnionym. In Podniesienie efektywności kształcenia uczniów ze specjalnymi potrzebami edukacyjnymi. Materiały dla nauczycieli. Warszawa: MEN.

Karwowska-Struczyk, M. (2007), Dziecko i konteksty jego rozwoju. Warszawa: IBE.

Kupisiewicz, Cz., Kupisiewicz, M. (2009). Słownik pedagogiczny. Warszawa: PWN.

Lewowicki, T. (1977). Indywidualizacja kształcenia. Dydaktyka różnicowa. Warszawa: PWN.

Limont, W. (2012). Uczeń zdolny. Jak go rozpoznać i jak z nim pracować. Sopot: GWP.

Okoń, W. (2007). Nowy słownik pedagogiczny. Warszawa: Wydawnictwo Akademickie ŻAK.

Palka, S. (2003). Pedagogika w stanie tworzenia. Kontynuacje. Kraków: Wydawnictwo Uniwersytetu Jagiellońskiego.

Piotrowski, E. (2008). Różnice indywidualne jako podstawa procesu indywidualizacji edukacji szkolnej. In J. Grzesiak (Eds.), Ewaluacja i innowacje w edukacji. Ewaluacja w dialogu - dialog w ewaluacji. Kalisz-Konin: Uniwersytet im. Adama Mickiewicza w Poznaniu, Wydział Pedagogiczno-Artystyczny w Kaliszu, Państwowa Wyższa Szkoła Zawodowa w Koninie, pp. 421-426.

Skrzetuska, E. (2011). Poziomy i wymiary indywidualizacji w edukacji wczesnoszkolnej. In E. Skrzetuska (Eds.), Problemy edukacji wczesnoszkolnej. Indywidualizacja - uzdolnienia - refleksja nauczyciela. Lublin: Wydawnictwo Uniwersytetu Marii CurieSkłodowskiej, pp. 37-60.

Strelau, J. (2006). Psychologia różnic indywidualnych. Warszawa: Wydawnictwo Naukowe SCHOLAR.

www.dzieci.us.edu.pl.

www.pierwszaki.com. 